this drug inhibits the growth of vibrios satisfactorily in a synthetic medium.

Three of the pteridines, $0 / 61,0 / 120$ and $0 / 129$, have been administered to mice in their diet at various concentrations over periods of three weeks. The maximal dietary concentration of each pteridine tolerated by eight out of ten animals is expressed in Table 2.

The fæces of mice feeding upon these experimental diets were collected, suspended and serially diluted in peptone water, autoclaved and sown with $V$. cholerce in the manner already described in detail (frecal suspension test ${ }^{6}$ ). In this test the highest dilution capable of inhibiting the growth of vibrios is called the 'fæcal vibriostatic titre'. As an example, we give in Table 2 the titres obtained when fæcal suspensions were sown with $10^{3}$ vibrios per $\mathrm{ml}$. and incubated at $37^{\circ} \mathrm{C}$. for $24 \mathrm{hr}$. It will be seen that $0 / 120$, administered at 0.4 per cent in the diet, confers a high titre upon the freces. The titre conferred by a diet containing 0.4 per cent of this pteridine is higher than that conferred by a diet containing 4 per cent sulphaguanidine, and the difference is even greater when the fæcal suspensions are inoculated with $10^{6}$ vibrios per ml.

Since Daniel and Norris ${ }^{3}$ have reported synergism between pteridines and sulphonamides, our more active compounds were examined for synergism with sulphaguanidine, which has been reported to be of clinical value in cholera (see Pasricha et al. ${ }^{7}$ ).

We have obtained good evidence of synergism, since, for example, in peptone water, under the same conditions of test as described above, a 10 per cent mixture of pteridine in sulphaguanidine exhibited a vibriostatic activity equal to that of the pure pteridine and far greater than that of sulphaguanidine alone (see Table 1). If incubation of the test cultures is continued for longer than $24 \mathrm{hr}$., the mixture considerably excels the pure pteridine in capacity to inhibit the growth of vibrios. $0 / 120$ is a partir] exception to this observation. It does, however, synergize to some extent with sulphaguanidine, as is seen in Table 1 and in the mouse experiments described below.

Mixtures of 10 per cent pteridine in sulphaguanidine were administered to mice in the diet. This was done by admixing in the diet 0.4 per cent pteridine and 3.6 per cent sulphaguanidine. The titres conferred by the pteridine sulphonamide mixture, as is seen in Table 2, are considerably higher than those conferred upon the fæces by either pteridine or sulphonamide alone. Chemical estimations of pteridines in the fæces support the view that the synergism shown in this table is real.

In mice the intraperitoneal $L D 50$ of the phosphates of pteridines $0 / 120$ and $0 / 129$ lies between 100 and $150 \mathrm{mgm}$. per kgm. However, in mixtures of pteridine $0 / 120$ with sulphaguanidine, the ingredients are not synergic but additive in their intraperitoneal toxicity. Moreover, in mixtures of pteridine 0/129 with sulphaguanidine the ingredients are neither synergic nor additive in their intraperitoneal toxicity.

We have found that a number of these compounds, such as $0 / 61,0 / 69$ and $0 / 120$, powerfully inhibit the growth of Strep. foecalis. In each instance the inhibitory effect on this organism is overcome by pteroylglutamic acid. This is consistent with the observations of Daniel and her co-workers on other compounds.

It is intended to publish shortly fuller accounts of the work upon which the above conclusions are based.
It is a pleasure to express our thanks to Dr. Cain for supplies of the $6: 7$-dimethyl- and $6: 7$-diphenyl2 : 4-diaminopteridines. We also wish to thank the directors of Allen and Hanburys, Ltd., for permission to publish this work.

${ }^{1}$ Mallette, M. F., Taylor, E. C., and Cain, C. K., J. Amer. Chem. Soc., 69, $1814(1947)$. ${ }^{2}$ Daniel, L. J., Norris, L. C., Scott, M. L., and Heuser, G. F., J. Biol.
Chem., 169, 089 (1947).

Daniel, L. J., and Norris, L. C., J. Biol. Chem., 170, 747 (1947).

Timmis, G. M., Nature, 164, 139 (1949).

${ }^{5}$ British Patent Application, No. 33393/49.

Collier, H. O. J., Hall, I. F. and Waterhouse, P. D., Ann. Trop. Med. Parasitol., 43, 155 (1949).

'Pasricha, C. L., Paul, B. M., Das Gupta, A. C., and Das, A. K., Ind. Med. Gaz., 82, 518 (1947).

\section{THE MIDLAND COKE RESEARCH STATION}

7 HE Midland Coke Research Station of the British Coke Research Association was formally inaugurated on May 4 by the Earl of Halifax. The Research Station, where problems on the production and utilization of coke from coke ovens are investigated, is in Clarkehouse Road, Sheffield, 10, about one mile from the centre of the city, and is conveniently close to the main buildings of the University of Sheffield and the University's Department of Fuel Technology in St. George's Square.

The Association was incorporated on June 20, 1944, as a grant-aided research organisation under the Department of Scientific and Industrial Research. Before that time, research on hard coke, that is, coke produced by carbonization of coal in oven chambers, had been carried out independently by the Midland, Northern and Scottish Coke Research Committees. These worked from their laboratories at Sheffield, Newcastle upon Tyne and Glasgow, respectively, and were controlled by regional committees representative of coke users, producers and other interested local organisations.

With the incorporation of the Association, the financing of research for the coking industry was undertaken by the British Coking Industry Association, and centralized control and co-ordination of research activities on coke became the responsibility of the council of the British Coke Research Association. The Association immediately undertook certain measures of reorganisation and drew up a comprehensive programme intended to cover the research work on coke for some years ahead, and to make full use of the facilities and staffs available in Sheffield and Neweastle.

It is apparent that the coking industry is located in certain well-defined regional areas, determined in large part by the availability of coking coal, and it is therefore not surprising to find that during the past twenty-five years the research work undertaken on coal and coke has acquired distinctly regional characteristics. The Association decided to encourage these characteristics by retaining the research establishments already existing at Sheffield and Newcastle and by promoting further research into local problems at Glasgow. In order to secure closer co-operation between the regional research workers and more intimate liaison with the operating tech. nicians of the industry, it was agreed that a system of panels should be set up to deal with certain specific items in the research programme, and that these 
panels should consist of members drawn from both sources. Although it was considered an innovation at the time of adoption, this system has proved both practicable and valuable to the research workers and the operating technicians alike.

The Association also decided at an early stage of its existence that it was most desirable to continue the system whereby work of an academic and long. term nature should be undertaken at the universities on behalf of the Association. This decision, since proved to be well justified, has resulted in a tendency to concentrate the academic and long-term researches of the industry at the laboratories of the Northern Coke Research Committee in King's College, Newcastle upon Tyne.

The Midland Coke Research Station has been developed concurrently from laboratories which were originally placed at the disposal of the Midland Coke Research Committee by the University of Sheffield. The Committee was formed in 1926 and was located in the Department of Fuel Technology until 1946, when, owing to increasing and insistent demands upon the available space, the University was reluctantly compelled to terminate this very generous arrangement. In view of the formation of the national body, the Midland Coke Research Committee decided that it should cease to function after the end of 1946 and the Association then agreed to establish its own research station in the Sheffield district, taking over the research staff who had worked hitherto for the Midland Coke Research Committee. Thus, from the earliest days of research on hard coke, there has been a long and valued connexion with the University of Sheffield, a connexion which the Association is proud to continue and which has proved to be of very great benefit to the cause of coke research during the past quarter of a century.

The Association approached the Sheffield Corpora. tion in its quest for suitable premises in which to accommodate the Midland Coke Research Station. The Corporation, which has always been keenly concerned in furthering matters affecting the interests of the basic industries centred in and around Sheffield, agreed to grant the Association the lease of a detached house owned by the Corporation and known as 'Lynwood', situated in its own grounds. The situation, facilities and amenities at 'Lynwood' render the Station very suitable for the type of work the Association is undertaking in Sheffield. The premises required some adaptation for the purposes of research, and this work was undertaken without delay. By the end of 1948 most of the structural alterations had been completed, and a start was made in equipping the buildings for research. On the ground floor are situated the superintendent's office and staff rooms, the general office and the library. Arrangements were made with the Coke Oven Managers' Association whereby its library was transferred to the Midland Coke Research Station, and became the property of the British Coke Research Association while being freely available to all members of the industry. Also on the ground floor are coke stores and a boiler test house. On the first floor, chemical and physical research laboratories were set up, together with a balance room, calorimetry room and chemical store; a general analytical laboratory was also established on this floor. A photographic department, stores and an electrical workshop were set up in the basement. The outbuildings have been converted into use as laboratories and workshops for various purposes. A laboratory has been provided for testing coke-burning appliances, and this has been equipped with means for carrying out efficiency and other tests on open grates, stoves, domestic hot-water boilers and small central-heating installations. The sampling and grinding arrangements available at the Station constitute probably the most efficient means yet devised for obtaining for purposes of analysis representative samples of finely ground coke from bulk consignments.

The research programme of the Association, which has been approved by the Department of Scientific and Industrial Research, covers the major problems facing the industry, and has been planned so that there is no unnecessary duplication of work with other organisations engaged on similar problems in fuel research, such as the Fuel Research Station, Gas Research Board and others. One of the major undertakings before the industry is the immense programme of reconstruction and repair which is at present in progress. It is important that the coke-oven batteries now being constructed should incorporate all the latest improvements and facilities available, and the Association, in conjunction with the principal British coke-oven construction organisations, has already made studies of such items as oven dimensions in relation to coal and coke qualities, and has investigated practical points of construction which are likely to improve the life of ovens, reduce operating and maintenance costs and give improved standards of working conditions. Close contact has been maintained with the progress of coke-oven plant design in the principal countries overseas engaged in this work.

It is well known that there is a shortage of the best-quality coking coals, and it is essential that these supplies should be conserved. This can be done only by extending supplies, which entails blending strongly caking coals with others of somewhat lower value. This problem is thus receiving special consideration, and the blending of high-quality coals with durain, fusain, coke dust, anthracite, pitch and tar have all been considered. A specification for an ideal plant lay-out to give full blending facilities has been devised. It is important that consumers of hard coke should receive the types of coke which are most suited to their needs, and investigation continues into means of producing the ideal coke for the three main purposes of blast furnace, foundry, and industrial and domestic use.

Coke produced for the iron and steel industry must have as low a sulphur content as possible; but unfortunately the sulphur content of the coking coals now being produced is increasing, and serious attention is being given to the possibility of reducing the sulphur content of coke by any possible means. For domestic use it is important that a coke be obtained which is convenient for household use, and this involves a control of the reactivity of the coke, together with the determination of the most suitable sizes for particular appliances.

It will be clear that many of the problems men. tioned above require investigation on an industrial scale and are inappropriate for work in the labor. atory. The station at Sheffield is primarily concerned with those matters which can be dealt with satisfactorily in the laboratory. One such major field is the development of chemical and physical tests of all types. Although the British Standards Institution publishes standard methods for the measurement of various quantities, it is not always convenient for industry to carry out the standard tests. Moreover, 
certain of these tests may be impracticable for normal works-control because of the time required for completion. Consideration has been given by the Associa. tion at the Research Station to the determination of analytical methods which will give the required accuracy together with rapid results.

Certain other tests especially required for the coking industry have not been standardized as yet by the British Standards Institution. A case in point is a test for the float and sink analysis of coal, and details of a method based on work carried out at the Station have been published. Considerable attention has been given also to means of screening coke, a problem which is by no means as straightforward as would appear.

Inquiries relating to the Association and its work should be addressed to the Director, British Coke Research Association, 74 Grosvenor Street, London, W.1.

\section{SOUTH-EASTERN UNION OF SCIENTIFIC SOCIETIES}

\section{ANNUAL CONGRESS}

$\mathrm{A}$

$T$ the invitation of the Mayor and Corporation of Richmond and of the president and Council of the Richmond Scientific Society, the South-Eastern Union of Scientific Societies held its fifty-fourth annual congress at Richmond during June 5-10.

The president was Dr. J. Ramsbottom, keeper of botany, British Museum (Natural History). The title of his presidential address was "The Biology of Peace". Dr. Ramsbottom reminded his audience that his previous address, given at Guildford in 1942, had for its subject "Fungi and the Biology of War", and that it was chiefly concerned with combating the idea that war is a biological necessity and that there were pure races of man pre-ordained for pre-eminence. The purpose of the present address was to put forward some ideas of the biology of peace. War of itself is of no biological use to man, though it must be granted that in the stress of two world wars there has resulted an accelerated development in the theory and application of science, both physical and biological, and the present 'cold war' is not without its influence in intensifying research. The pity of it is that fear and distrust among nations should have such a disproportionate influence on progress of any kind. No matter what his philosophy, the man of science is dealing with what might be generalized as the phenomena of Nature, the discovery of the laws which govern the universe, and the intrinsic nature and properties of its constituents. There have been repeated warnings about the danger of a world food shortage. Fundamentally, the problem resolves itself into the number of people and the amount of food. Populations continue to increase and we are unable to produce sufficient food or timber for our use.

Man should not represent himself as against the world-Homo contra mundum-but of it. Every organism is affected by its environment and in its turn affects it : indeed, it is best to regard an organism as part and parcel of its environment; and man, biologically, is an organism. The complex which we signify by the term environment has a theoretical stability, a climax. In Great Britain the vegetation climax is a forest; but it is sometimes overlooked that it is the whole community signified by the term forest -trees, shrubs, herbs, mosses, liverworts, algæ, fungi, lichens, bacteria and a similar gamut of the animal kingdom; in short, the whole complex of organisms above, on and under the ground.

Dr. Ramsbottom proceeded to stress the need for the protection of the countryside and the preservation of species. When once a species is exterminated it is lost for ever. Destruction is not confined to shooting and trapping, it is inevitable if the habitat is greatly altered. In schemes for preservation the climatic, edaphic and biological factors must be understood. Biological factors include man's activities.

The problems relating to world food supplies are such that they have to be studied from all angles : integration of research to prevent disintegration of our future. We have modified above and below the earth's crust, we have been profligate in our actions, but mankind still manages to survive. Continuing, Dr. Ramsbottom remarked that to make a few suggestions of simple remedies would savour of an election address of an illiterate demagogue. There is no universal panacea for human ills, be they spiritual, physical or economical. With all our efforts, be they ever so well directed, shall we be able so to balance our industrial and agricultural matters that we produce sufficient food and timber for our needs ? One solution which has been suggested for Great Britain is to reduce the population. Emigra. tion of one-third of the population of Britain to other parts of the Commonwealth would save enormous capital and naturäl resources. Dr. Ramsbottom said that he confessed to an undaunted optimism, for where danger lies, there also grows the saving power. Great Britain may not remain so powerful in a naval, military and air sense, but there is no danger of it becoming a desert and so no possibility of it being written off as derelict. Indiscriminate felling of forests, fires, overgrazing, continuous single crops, lack of the use of fertilizers and the untethered goat all have their effect on the vegetation, fertility and cohesion of the soil and lead to erosion and deserts. Mistakes have been made, but it should not be beyond the powers of man to turn the tide and even repair the damage. It must not be overlooked that algæ, and particularly fungi, can supply us with supplementary proteins and other foods. Gastronomic salvation may be by way of flowerless plants, but the monotony of the diet would possibly mean the loss of one type of man-the gourmet.

The members of the Congress were received by the Mayor of Richmond (Councillor P. H. Keene) who, in his welcome, spoke of the value of science to the community. A young naturalists' evening was arranged, and questions were answered by a team of experts with Major Maxwell Knight as the question master, and an exhibition of Nature films was arranged by Mr. Douglas Fisher.

Addresses were delivered to the Archæological, Botanical, Geological and Zoological Sections and excursions carried out by these Sections daily. Colour films of botanical expeditions to Thibet were shown by Dr. George Taylor.

The final address was by Mr. E. J. King, of the Department of Extra-Mural Studies, University of London, on "The Scientific Societies and the University". In speaking of the mutual advantage of co-operation between universities and societies, he stressed that academic interest must not interfere with general interest and enthusiasm. The general 